\title{
Characterization of Ambient Particulate Matters in an Industry-Intensive Area in Central Taiwan
}

\author{
Hsing-Wang Li ${ }^{1}$, Kang-Shin Chen ${ }^{2}$, Chia-Hsiang Lai ${ }^{3}$, Ting-Yu Chen ${ }^{4}$, Yi-Ching Lin ${ }^{2}$, Yung-Chang Lin ${ }^{5}$, \\ Chia-Hung Chen ${ }^{2}$, Yen-Ping Peng ${ }^{2, *}$ and Ming-Hsun Lin ${ }^{6, *}$
}

1 New Materials Research \& Development Department, China Steel Corporation, Kaohsiung 812, Taiwan; leestanly@yahoo.com.tw

2 Institute of Environment Engineering, National Sun Yat-sen University, Kaohsiung 804, Taiwan; shin@mail.nsysu.edu.tw (K.-S.C.); yclin@gcloud.csu.edu.tw (Y.-C.L.); chiahungchen@g-mail.nsysu.edu.tw (C.-H.C.)

3 Department of Biotechnology, National Formosa University, Yunlin 632, Taiwan; chlai2@ctust.edu.tw

4 Department of Environmental Science and Engineering, Tunghai University, Taichung 407, Taiwan; tingyu84@kcg.gov.tw

5 Center for Environmental Toxin and Emerging-Contaminant Research, Cheng Shiu University, Kaoshiung 833, Taiwan; yichinglin@mail.nsysu.edu.tw

6 Department of Marine Environmental Engineering, National Kaohsiung University of Science and Technology, Kaohsiung 81157, Taiwan

* Correspondence: yppeng@mail.nsysu.edu.tw (Y.-P.P.); m9033617@nkust.edu.tw (M.-H.L.); Tel.: +886-7-5252-000\#4422 (Y.-P.P.); +886-7-3165-288 (M.-H.L.); Fax: +886-7-5254-449 (Y.-P.P.)

check for updates

Citation: Li, H.-W.; Chen, K.-S.; Lai, C.-H.; Chen, T.-Y.; Lin, Y.-C.; Lin, Y.-C.; Chen, C.-H.; Peng, Y.-P.; Lin, M.-H. Characterization of Ambient Particulate Matters in an Industry-Intensive Area in Central Taiwan. Atmosphere 2021, 12, 926. https: / / doi.org/10.3390/

atmos12070926

Academic Editor: Prashant Kumar

Received: 15 June 2021

Accepted: 15 July 2021

Published: 18 July 2021

Publisher's Note: MDPI stays neutral with regard to jurisdictional claims in published maps and institutional affiliations.

Copyright: (c) 2021 by the authors. Licensee MDPI, Basel, Switzerland. This article is an open access article distributed under the terms and conditions of the Creative Commons Attribution (CC BY) license (https:/ / creativecommons.org/licenses/by/ $4.0 /)$.

\begin{abstract}
Atmospheric particulate matters (PMs) were measured in an industry-intensive region in central Taiwan in order to investigate the characteristics and possible sources of PMs. The samplings were simultaneously conducted using a 10- and 3-stage Micro Orifice Uniform Deposit Impactor (MOUDI) from 2017 to 2018. In this study, the characteristics of PMs in this region were evaluated by measuring the mass concentration of PMs and analyzing water-soluble ions and metallic elements, as well as dioxins. Additionally, principal component analysis (PCA) was used to identify the potential sources of PMs. The results showed that the mean concentration of coarse $(>1.8 \mu \mathrm{m})$, fine $(0.1-1.8 \mu \mathrm{m})$, and ultrafine $(<0.1 \mu \mathrm{m})$ particles were $13.60,14.38$, and $3.44 \mu \mathrm{g} / \mathrm{m}^{3}$, respectively. In the industry-intensive region, the size distribution of ambient particles showed a bi-modal distribution with a high concentration of coarse particles in the spring and summer, while fine particles were dominant in the autumn and winter. The most abundant water-soluble ions of $\mathrm{PMs}$ were $\mathrm{NO}_{3}{ }^{-}, \mathrm{Cl}^{-}$, and $\mathrm{SO}_{4}{ }^{2-}$, while the majority of metallic elements were $\mathrm{Na}, \mathrm{Fe}, \mathrm{Ca}, \mathrm{Al}$, and $\mathrm{Mg}$ in different particle sizes. The results of Pearson's correlation analysis for metals indicated that the particles in the collected air samples were related to the iron and steelmaking industries, coal burning, vehicle exhausts, and high-tech industries. The dioxin concentration ranged from 0.0006 to $0.0017 \mathrm{pg}$ I-TEQ/ $\mathrm{Nm}^{3}$. Principal component analysis (PCA) revealed that the contribution to PMs was associated with sea salt, secondary pollutants, and industrial process.
\end{abstract}

Keywords: PMs; size distribution; chemical composition; PCA

\section{Introduction}

Air pollution is a major concern in urban areas because of its threat to human health, including asthma and acute and chronic respiratory symptoms [1]. Ambient particulate matters (PMs) include small solid or liquid particles suspended in the air. In addition, PMs included particles with an aerodynamic diameter of less than $0.1 \mu \mathrm{m}$, less than $2.5 \mu \mathrm{m}$, and less than $10 \mu \mathrm{m}$, also known as $\mathrm{PM}_{1}, \mathrm{PM}_{2.5}$, and $\mathrm{PM}_{10}$, respectively [2]. Epidemiological studies reported that the highest association noted was an $18 \%$ rise in asthma admissions correlated with a $10 \mu \mathrm{g} / \mathrm{m}^{3}$ increase in coarse particles on the same day of admissions [3]. Furthermore, ultrafine particles cause a stronger toxic effect than 
fine and coarse particles due to their high surface area [4,5]. The chemical compositions of PMs include water-soluble ions, metallic elements, and organic compounds, such as dioxin, which are correlated to toxicity and health [6,7]. Typically, the ionic constituents accounted for $35-60 \%$ of the $\mathrm{PM}_{2.5}$ mass in Korea, and sulfates and nitrates were the dominant ionic species [8]. In southern Taiwan, Tsai et al. [9] reported that sulfate, nitrate, and ammonium were the major ionic species and contributed a large fraction of PM mass in different sizes. In Boston, over $80 \%$ of the elements mostly found in the coarse mode included $\mathrm{Ca}, \mathrm{Mn}$ (road dust), and $\mathrm{Cl}$ (sea salt) [10]. In Mexico City, high concentrations of $\mathrm{Al}, \mathrm{Cr}, \mathrm{Ni}, \mathrm{Pb}$, and $\mathrm{V}$ were measured in late fall [11]. PCDD/Fs have been a source of much public concern over the last decade due to adverse health effects [6]. The dioxin concentration in the atmosphere could be affected by different seasons because of domestic heating, photolysis, and chemical reactions [12]. In rural Germany, PCDD/F concentrations were higher in the winter than in the summer due to domestic heating [13].

The main objectives of this study were to investigate the characteristics of ambient PMs in an industrial area. The different particle sizes of PMs, including coarse, fine, and ultrafine modes, were measured, as well as water-soluble ions, metallic elements, and dioxins in PMs. The principal component analysis (PCA) is a useful statistical method to assess possible sources of pollution and their contribution to ambient PMs. The results of this study are of great importance to understand the characteristic of PMs in an industrial area and will provide useful information for the future control strategy of ambient PMs.

\section{Experiment and Methods}

\subsection{Sampling of $P M$}

The atmospheric particle sampling site was designed according to the understanding of local emission sources. The atmospheric particle samplings were taken at the campus of Tunghai University in central Taiwan as a receptor for assessment. The sampling site was surrounded by Taichung Industrial Park (A: $500 \mathrm{~m}$ away), Central Taiwan Science Park (B: $4 \mathrm{~km}$ away), and Taichung Power Station (C: $10 \mathrm{~km}$ away) (Figure 1). The samples were collected continuously for $24 \mathrm{~h}$ on four consecutive days during all four seasons in 2017 and 2018. This study employed two 10-stage and 3-stage cascade impactors from Micro-Orifice Uniform Deposit Impactors (MOUDI) (Model 110-R, 100S4; MSP Corporation, in Shoreview, MN, USA). The corresponding cut-off sizes were $0.056,0.10,0.18,0.32,0.56,1.0,1.8,3.2,5.6,10.0,18 \mu \mathrm{m}$, and 1.0, 2.5, and $18 \mu \mathrm{m}$, respectively. A $47 \mathrm{~mm}$ Teflon filter was used to collect the samples with a flow rate of $30 \mathrm{~L} / \mathrm{min}$. The filters were conditioned at $25 \pm 3{ }^{\circ} \mathrm{C}$ and $45 \pm 5 \%$ relative humidity for $24 \mathrm{~h}$ before weighing. In addition, PCDD/Fs were collected by a PS-1 sampler that was equipped with quartz fiber filters.

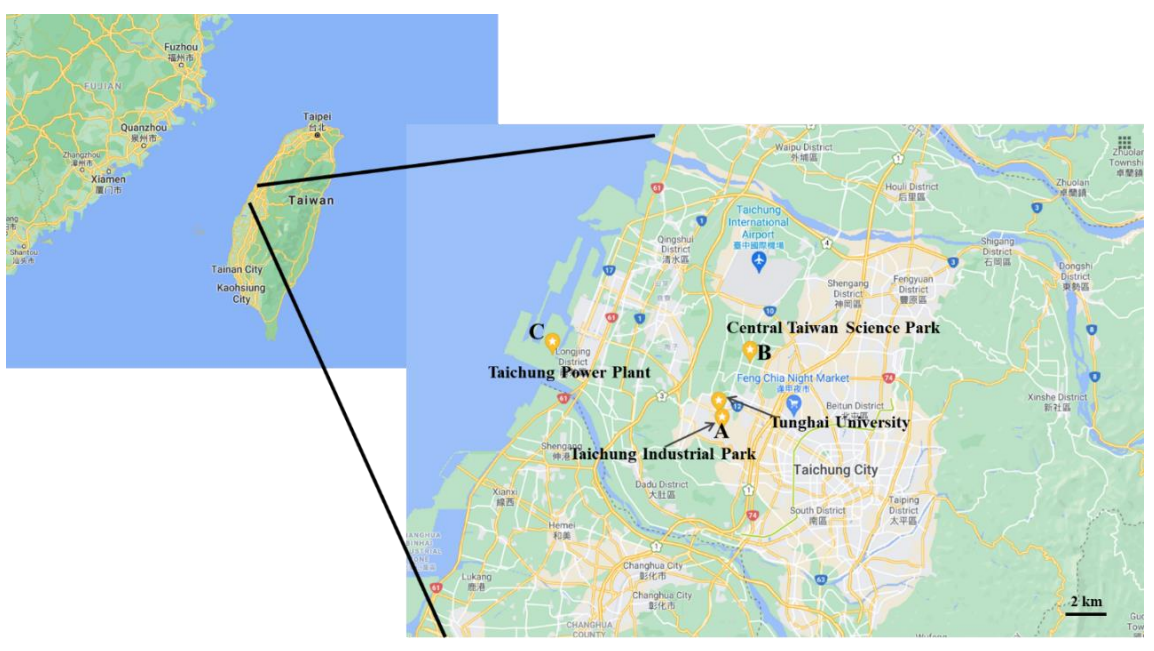

Figure 1. Schematic diagram of sampling site (Tunghai University) and the surrounding pollution sources (A: Taichung Industrial Park; B: Central Taiwan Science Park; C: Taichung Power Plant). The figure is reproduced from Google map at $24^{\circ} 10^{\prime} 54.1^{\prime \prime} \mathrm{N} 120^{\circ} 36^{\prime} 24.7^{\prime \prime} \mathrm{E}$. 


\subsection{Analysis of Water-Soluble Ions and Metallic Elements}

Water-soluble cations and anions were analyzed by ion chromatography according to the standard method of the Taiwan Environment Protection Agency (EPA): NIEA W415.54B. One-half of each Teflon filter was analyzed by ion chromatography (Metrohm, 883 Basic IC plus). Each filter was put into a polyethylene bottle with $10 \mathrm{~mL}$ deionized distilled water and was extracted using an ultrasonic bath for $60 \mathrm{~min}$. The extract was filtered with an acetate filter with $0.22 \mu \mathrm{m}$ pore size diameter. Five cations $\left(\mathrm{Na}^{+}, \mathrm{NH}_{4}{ }^{+}, \mathrm{K}^{+}, \mathrm{Mg}^{2+}, \mathrm{Ca}^{2+}\right)$ and five anions $\left(\mathrm{F}^{-}, \mathrm{Cl}^{-}, \mathrm{NO}_{2}{ }^{-}, \mathrm{NO}_{3}{ }^{-}, \mathrm{SO}_{4}{ }^{2-}\right.$ ) were analyzed by ion chromatography (Metrohm, 883 Basic IC plus). The anion species were detected by Metrosep C 4-150/4.0 $(4 \times 150 \mathrm{~mm})$ analytical column with an effluent of $1.7 \mathrm{mM} \mathrm{HNO}_{3} / 0.7 \mathrm{mM} \mathrm{C}_{7} \mathrm{H}_{5} \mathrm{NO}_{4}$ at a flow rate of $0.9 \mathrm{~mL} / \mathrm{min}$. The cation species were separated by Metrosep A Supp5-150/4.0 $(4 \times 150 \mathrm{~mm})$ analytical column with an effluent of $1.0 \mathrm{mM} \mathrm{NaHNO} / 3.3 \mathrm{mM} \mathrm{NaCO}_{3}$ at a flow rate of $0.7 \mathrm{~mL} / \mathrm{min}$. The detection limits were $0.20,0.18,0.11,0.42,0.36,0.59,0.46,0.48,0.15$, and $0.5 \mu \mathrm{g} / \mathrm{L}_{\text {for }} \mathrm{Na}^{+}, \mathrm{NH}_{4}{ }^{+}, \mathrm{K}^{+}, \mathrm{Mg}^{2+}$, $\mathrm{Ca}^{2+}, \mathrm{Cl}^{-}, \mathrm{NO}_{3}{ }^{-}, \mathrm{SO}_{4}{ }^{2-}, \mathrm{NO}_{2}{ }^{-}$, and $\mathrm{F}^{-}$, respectively.

The metals were analyzed by inductively coupled plasma mass spectrometry according to the standard method of NIEA A306.10C of the Taiwan Environment Protection Agency (EPA). The other half of the Teflon filter was analyzed to clarify the metal concentrations. The Teflon filters were placed in a microwave digestion furnace and were heated at $175{ }^{\circ} \mathrm{C}$ for $10 \mathrm{~min}$, and then 24 metals $(\mathrm{Zn}, \mathrm{Cd}, \mathrm{Co}, \mathrm{Cr}, \mathrm{Cu}, \mathrm{Fe}, \mathrm{Ga}, \mathrm{In}, \mathrm{Mn}, \mathrm{Ni}, \mathrm{Pb}, \mathrm{Sr}, \mathrm{Ag}$, $\mathrm{B}, \mathrm{Ba}, \mathrm{Bi}, \mathrm{Ca}, \mathrm{K}, \mathrm{Li}, \mathrm{Mg}, \mathrm{Na}, \mathrm{Tl}, \mathrm{As}$, and $\mathrm{Al}$ ) were analyzed by inductively coupled plasma mass spectrometry (Thermo Scientific, iCAP RQ). The method detection limits for $\mathrm{Zn}, \mathrm{Cd}$, $\mathrm{Co}, \mathrm{Cr}, \mathrm{Cu}, \mathrm{Fe}, \mathrm{Ga}, \mathrm{In}, \mathrm{Mn}, \mathrm{Ni}, \mathrm{Pb}, \mathrm{Sr}, \mathrm{Ag}, \mathrm{B}, \mathrm{Ba}, \mathrm{Bi}, \mathrm{Ca}, \mathrm{K}, \mathrm{Li}, \mathrm{Mg}, \mathrm{Na}, \mathrm{Ti}, \mathrm{As}$, and $\mathrm{Al}$ were $0.55,0.89,0.66,0.88,0.63,0.92,0.78,0.98,0.55,0.66,1.75,0.56,0.65,1.63,0.37,0.78,0.62,0.57$, $0.36,1.45,0.45,1.34,1.23$, and $1.55 \mathrm{ug} / \mathrm{L}$, respectively. For clarity, the samples are divided into coarse $(>1.8 \mu \mathrm{m})$, fine $(0.1-1.8 \mu \mathrm{m})$, and ultrafine $(<0.1 \mu \mathrm{m})$ particles.

\subsection{Analysis of $P C D D / F s$}

Analysis of ambient air samples for PCDD/Fs was performed according to the US EPA Reference Method TO9A [14]. Each sample was spiked with a known amount of the internal standard. All samples were extracted with toluene for $24 \mathrm{~h}$, and this was then followed by a series of sample cleanup and fractionation procedures. The extract was transferred to a vial and further concentrated by a $\mathrm{N}_{2}$ gas stream. High-resolution gas chromatographs/high-resolution mass spectrometers (HRGC/HRMS) were used for PCDD/F analysis. The HRGC (Hewlett-Packard 6970 Series gas, Atalanta, CA, USA) was equipped with a DB-5 fused silica capillary column ( $\mathrm{L}=60 \mathrm{~m}$, ID $=0.25 \mathrm{~mm}$, film thickness $=0.25 \mu \mathrm{m})(\mathrm{J} \& \mathrm{~W}$ Scientific, Atalanta, CA, USA) with a splitless injection, while the HRMS (Micromass Autospec Ultima, Manchester, UK) had a positive electron impact $\left(\mathrm{EI}^{+}\right)$source. The oven temperature program was set according to the following: start at $150{ }^{\circ} \mathrm{C}$ (held for $1 \mathrm{~min}$ ), then increased by $30^{\circ} \mathrm{C} / \mathrm{min}$ to $220^{\circ} \mathrm{C}$ (held for $12 \mathrm{~min}$ ), and finally increased by $1.5^{\circ} \mathrm{C} / \mathrm{min}$ to $310^{\circ} \mathrm{C}$ (held for $20 \mathrm{~min}$ ). Helium was used as the carrier gas. Laboratory blank samples were also sampled and analyzed for quality assurance purposes. The PCDD/F mass of method blank samples for the tetra through hexa-chlorinated homologues ranged from 0.79 to $1.58 \mathrm{pg}$, while that for the hepta- and octa-chlorinated homologues ranged from 0.19 to $0.70 \mathrm{pg}$.

\subsection{Principal Component Analysis}

Principal component analysis (PCA) is widely used as an assessment method to identify possible pollution sources. PCA is applied to characterize large sets of data by re-expressing to a rotated coordinate system in which the eigenvectors of the variancecovariance matrix are calculated to explain as much variance as possible. The principal component score, i.e., the weight of the eigenvector, can be obtained. These scores of the original variables, called the principal component loadings (PC loadings), can illustrate the relationship between the variable and the principal component. The first PC (PC1) will explain most of the variance of the original data variables, whereas the second PC (PC2) will explain fewer of the original data variables. By doing this, the raw data matrix can 
be reduced to two or three principal component loadings that account for the majority of the variance. The PCA provides qualitative information about the nature of the source profile compositions and the relative importance of a given source to the observed concentration [15]. The main objective of PCA is to reduce a large number of variables to a smaller set of factors that retain most of the information in the original data set $[16,17]$. Each factor explains the maximum total variance of the data set, and this set is completely uncorrelated with the rest of the data. Thus, the elements with higher factor loading $(>0.7)$ are interpreted as fingerprints of emission sources [18].

\section{Results and Discussion}

\subsection{Particulate Matter Mass Concentrations and Particle Size distribution}

The mass concentration of coarse $(>1.8 \mu \mathrm{m})$, fine $(0.1-1.8 \mu \mathrm{m})$, and ultrafine $(<0.1 \mu \mathrm{m})$ particles are listed in Table 1 . The order of the mass of particle sizes in spring and summer was coarse particles $>$ fine particles $>$ ultrafine particles, while those in autumn and winter were fine particles $>$ coarse particles $>$ ultrafine particles. The coarse particles were dominant in spring and summer, with an average mass concentration of 16.96 and $12.67 \mu \mathrm{g} / \mathrm{m}^{3}$, accounting for 47.5 and $45.6 \%$, respectively. The concentration of the fine particles was 15.39 and $18.17 \mu \mathrm{g} / \mathrm{m}^{3}$ in autumn and winter, accounting for 46.7 and $62.2 \%$, respectively. In summer, the mass levels of coarse, fine, and ultrafine particles were $12.67,9.14$, and $5.96 \mu \mathrm{g} / \mathrm{m}^{3}$, respectively, and were slightly higher than those in the Shanghai urban summer atmosphere $(9.38,8.82$, and $\left.2.02 \mu \mathrm{g} / \mathrm{m}^{3}\right)$ and the traffic site in Los Angeles $\left(6.3,5.8\right.$, and $\left.1.7 \mu \mathrm{g} / \mathrm{m}^{3}\right)[19,20]$. Therefore, the particle concentration in this industrial area is relatively polluted compared to the references [19,20], and the mass level was different in different seasons. In addition, the $\mathrm{PM}_{10}$ concentration was measured as being from 9.26 to $42.59 \mu \mathrm{g} / \mathrm{m}^{3}$, which is close to values of the previous study in central Taiwan [21]. Our data showed slightly lower values than the $\mathrm{PM}_{10}$ concentration of $13.83-53.67 \mu \mathrm{g} / \mathrm{m}^{3}$ at Xitun station (one of the EPA air quality monitoring stations) due to the difference between the automatic and manual sampling methods. In addition, the $\mathrm{PM}_{10}$ data were much lower than the Taiwan EAP $\mathrm{PM}_{10}$ regulations $\left(125 \mu \mathrm{g} / \mathrm{m}^{3}\right)$. The ambient PMs displayed a bimodal distribution, as shown in Figure 2. In spring and summer, the most prominent peak occurred in the range of $\mathrm{Dp}=3.2-5.6 \mu \mathrm{m}$, and the minor peak was in the range of $\mathrm{Dp}=0.18-0.32 \mu \mathrm{m}$. In autumn and winter, the most prominent peak occurred in the range of $\mathrm{Dp}=0.32-0.56 \mu \mathrm{m}$, and the minor peak was in the range of $\mathrm{Dp}=3.2-5.6 \mu \mathrm{m}$. These results are similar to a previous study in that coarse particles were the predominant components in spring [22]. The cumulative mass fractions for fine particles were 41.8 and $33.4 \%$ in spring and summer, respectively, while they accounted for 51.8 and $62.5 \%$ in autumn and winter, respectively (Figure 3). This indicated that fine particle pollution is dominant in Taichung in autumn and winter. In addition, both coarse and fine particles were associated with local traffic [23].

Table 1. The mass concentration of different particle sizes (coarse, fine, ultrafine particles).

\begin{tabular}{ccccccc}
\hline \multirow{2}{*}{$\begin{array}{c}\text { Sampling } \\
\text { Time }\end{array}$} & \multicolumn{2}{c}{$\begin{array}{c}\text { Coarse Particles } \\
\left(\mu \mathrm{g} / \mathrm{m}^{\mathbf{3}}\right)\end{array}$} & \multicolumn{2}{c}{$\begin{array}{c}\text { Fine Particles } \\
\left(\mu \mathrm{g} / \mathbf{m}^{\mathbf{3}}\right)\end{array}$} & \multicolumn{2}{c}{$\begin{array}{c}\text { Ultrafine Particles } \\
\left(\mu \mathrm{g} / \mathbf{m}^{\mathbf{3}}\right)\end{array}$} \\
\cline { 2 - 7 } & Mean & SD & Mean & SD & Mean & SD \\
\hline Spring & 16.96 & 3.9 & 14.82 & 5.7 & 3.94 & 0.9 \\
Summer & 12.67 & 3.3 & 9.14 & 1.7 & 5.96 & 3.7 \\
Autumn & 14.99 & 1.8 & 15.39 & 3.0 & 2.61 & 0.5 \\
Winter & 9.78 & 5.8 & 18.17 & 10.0 & 1.27 & 0.1 \\
\hline
\end{tabular}



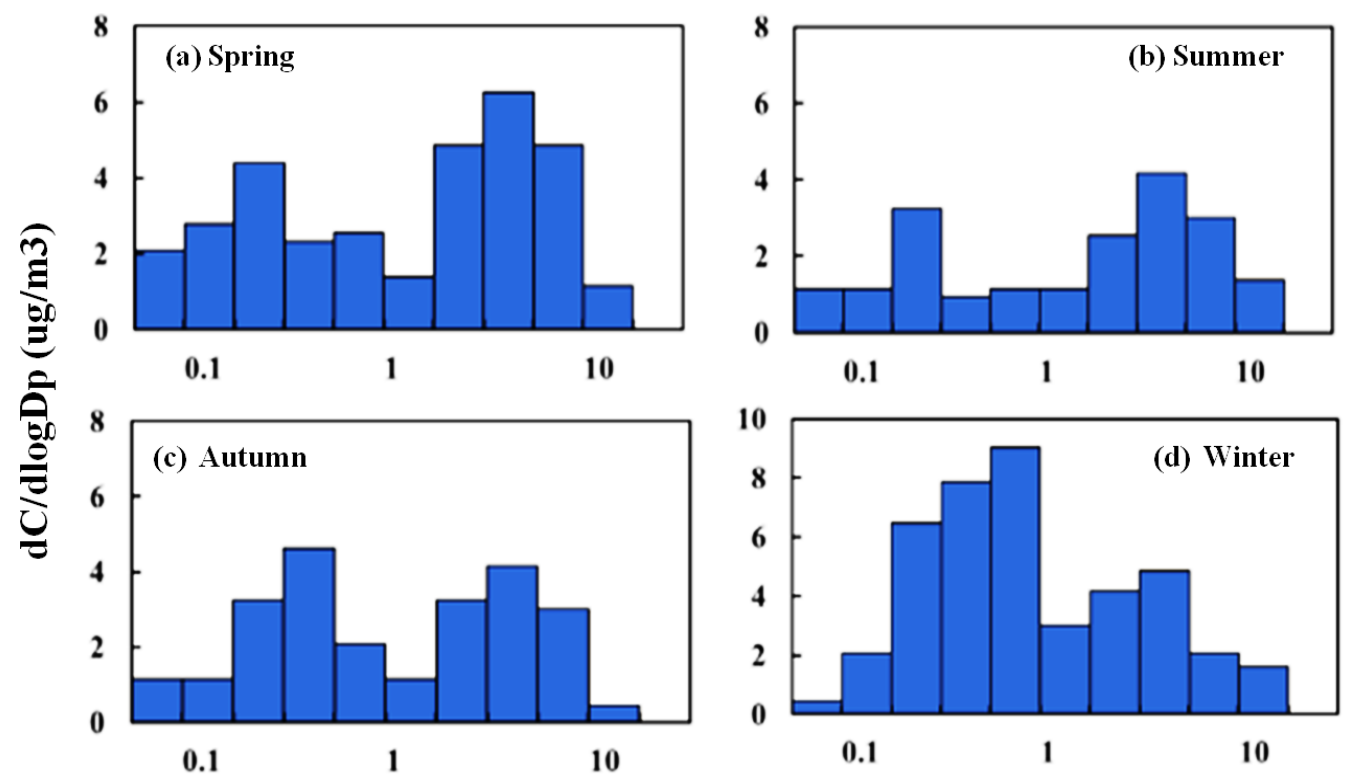

Particle diameter (um)

Figure 2. Particle size distributions: (a) Spring; (b) Summer; (c) Autumn; (d) Winter.
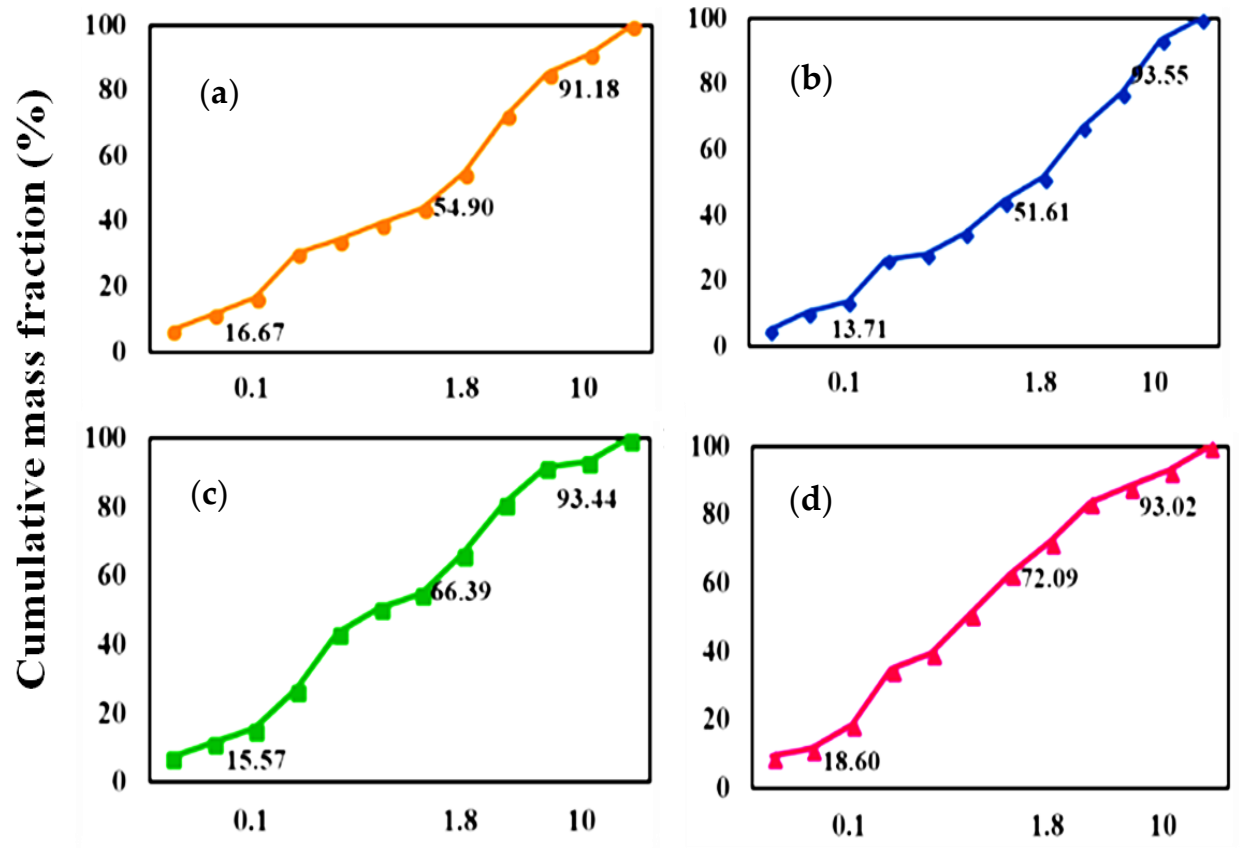

\section{Particle diameter (um)}

Figure 3. Cumulative mass fractions of particulate matter: (a) Spring; (b) Summer; (c) Autumn; (d) Winter.

\subsection{Water-Soluble Ions}

Table 2 shows the water-soluble ion content in different particle sizes. The sequence of the major ionic species in the coarse particles was $\mathrm{Cl}^{-}\left(1.63 \pm 0.41 \mu \mathrm{g} / \mathrm{m}^{3}\right)>$ $\mathrm{NO}_{3}{ }^{-}\left(1.62 \pm 0.61 \mu \mathrm{g} / \mathrm{m}^{3}\right)>\mathrm{SO}_{4}{ }^{2-}\left(1.18 \pm 0.29 \mu \mathrm{g} / \mathrm{m}^{3}\right)>\mathrm{Na}^{+}\left(0.90 \pm 0.52 \mu \mathrm{g} / \mathrm{m}^{3}\right)$, while the sequence was $\mathrm{SO}_{4}{ }^{2-}\left(2.32 \pm 1.03 \mu \mathrm{g} / \mathrm{m}^{3}\right)>\mathrm{Cl}^{-}\left(1.37 \pm 0.29 \mu \mathrm{g} / \mathrm{m}^{3}\right)>$ $\mathrm{NO}_{3}{ }^{-}\left(1.30 \pm 1.02 \mu \mathrm{g} / \mathrm{m}^{3}\right)>\mathrm{NH}_{4}{ }^{+}\left(1.24 \pm 1.01 \mu \mathrm{g} / \mathrm{m}^{3}\right)$ for the fine particles. Huang et al. (2013) reported that the dominant species were $\mathrm{SO}_{4}{ }^{2-}, \mathrm{Cl}^{-}, \mathrm{NO}_{3}{ }^{-}$, and $\mathrm{NH}_{4}{ }^{+}$at an industrial complex site in China. $\mathrm{SO}_{4}{ }^{2-}, \mathrm{NH}_{4}{ }^{+}$, and $\mathrm{NO}_{3}{ }^{-}$are considered to be the major secondary aerosols 
by anthropogenic sources [24]. Regarding ultrafine particles, the majority of components were $\mathrm{SO}_{4}{ }^{2-}\left(0.44 \pm 0.20 \mu \mathrm{g} / \mathrm{m}^{3}\right), \mathrm{Cl}^{-}\left(0.41 \pm 0.25 \mu \mathrm{g} / \mathrm{m}^{3}\right), \mathrm{NO}_{3}{ }^{-}\left(0.26 \pm 0.09 \mu \mathrm{g} / \mathrm{m}^{3}\right)$, and $\mathrm{Na}^{+}\left(0.23 \pm 0.28 \mu \mathrm{g} / \mathrm{m}^{3}\right)$, accounting for $62.05 \%$ of the total species. The $\mathrm{Cl}^{-}$in both the coarse and fine particles is generally derived from sea spray [25]. Motor vehicle emissions and fossil fuel combustion are the dominant contributors to $\mathrm{NO}_{3}{ }^{-}$and $\mathrm{SO}_{4}{ }^{2-}$, respectively $[26,27]$. In addition, the high concentration of $\mathrm{Cl}^{-}$and $\mathrm{K}^{+}$during the heating season may be due to increased coal combustion [28] and straw burning [29]. Notably, the $\mathrm{K}^{+}$concentration $\left(0.16-0.35 \mu \mathrm{g} / \mathrm{m}^{3}\right)$ was not relatively high in this study because the sampling site is $10 \mathrm{~km}$ away from Taichung Power Station (see Figure 1). Compared with other cities, water-soluble constituents contributed an average of $11.57 \%$ in $\mathrm{PM}_{2.5}$ and $16.98 \%$ in $\mathrm{PM}_{1}$ in Drug city in India. Notably, similar to our study, the concentrations of $\mathrm{SO}_{4}{ }^{2-}$ and $\mathrm{NO}_{3}{ }^{-}$were high in all size fractions and accounted for $32.76 \%$ and $13.38 \%$ of the total mass of the water-soluble ions in $\mathrm{PM}_{2.5}$ [30]. In Palermo, Italy, a large fraction of $\mathrm{PM}_{10}$ (31-47\% in weight) and $\mathrm{PM}_{2.5}(29 \%$ in weight) are made up of water-soluble ions. $\mathrm{SO}_{4}{ }^{2-}$ and $\mathrm{NH}_{4}{ }^{+}$concentrations in the $\mathrm{PM}_{2.5}$ fraction were higher than in $\mathrm{PM}_{10} . \mathrm{SO}_{4}{ }^{2-}, \mathrm{NH}_{4}{ }^{+}$, and $\mathrm{NO}_{3}{ }^{-}$ions also constituted $51-63 \%$ of the total measured water-soluble ions [31]. In the electronic processing industrial region of Kunshan, China, the most abundant ions are $\mathrm{NO}_{3}{ }^{-}\left(30.96 \mu \mathrm{g} / \mathrm{m}^{3}\right), \mathrm{SO}_{4}{ }^{2-}\left(24.67 \mu \mathrm{g} / \mathrm{m}^{3}\right)$, and $\mathrm{NH}_{4}{ }^{+}\left(19.98 \mu \mathrm{g} / \mathrm{m}^{3}\right)$, and are significantly higher than those found in this study [32].

Table 2. The content of water-soluble ions in different particle sizes.

\begin{tabular}{ccccccc}
\hline $\begin{array}{c}\text { Water-Soluble } \\
\text { Ions }\end{array}$ & \multicolumn{2}{c}{$\begin{array}{c}\text { Coarse Particles } \\
\left(\mu \mathrm{g} / \mathbf{m}^{3}\right)\end{array}$} & \multicolumn{2}{c}{$\begin{array}{c}\text { Fine Particles } \\
\left(\mu \mathrm{g} / \mathbf{m}^{\mathbf{3}}\right)\end{array}$} & \multicolumn{2}{c}{$\begin{array}{c}\text { Ultrafine Particles } \\
\left(\boldsymbol{\mu g} / \mathbf{m}^{\mathbf{3}}\right)\end{array}$} \\
\cline { 2 - 7 } & Mean & SD & Mean & SD & Mean & SD \\
\hline $\mathrm{Na}^{+}$ & 0.90 & \pm 0.52 & 0.43 & \pm 0.39 & 0.23 & \pm 0.28 \\
$\mathrm{NH}_{4}^{+}$ & 0.30 & \pm 0.10 & 1.24 & \pm 1.01 & 0.16 & \pm 0.05 \\
$\mathrm{~K}^{+}$ & 0.35 & \pm 0.16 & 0.32 & \pm 0.11 & 0.16 & \pm 0.21 \\
$\mathrm{Ca}^{2+}$ & 0.47 & \pm 0.18 & 0.25 & \pm 0.17 & 0.09 & \pm 0.08 \\
$\mathrm{Mg}^{2+}$ & 0.20 & \pm 0.17 & 0.11 & \pm 0.10 & 0.04 & \pm 0.05 \\
$\mathrm{~F}^{-}$ & 0.35 & \pm 0.28 & 0.35 & \pm 0.25 & 0.13 & \pm 0.13 \\
$\mathrm{Cl}^{-}$ & 1.63 & \pm 0.41 & 1.37 & \pm 0.29 & 0.41 & \pm 0.25 \\
$\mathrm{NO}_{3}{ }^{-}$ & 1.62 & \pm 0.61 & 1.30 & \pm 1.02 & 0.26 & \pm 0.09 \\
$\mathrm{SO}_{4}{ }^{2-}$ & 1.18 & \pm 0.29 & 2.32 & \pm 1.03 & 0.44 & \pm 0.20 \\
\hline
\end{tabular}

\subsection{Metallic Elements}

The fraction of metals in coarse particles in different seasons is shown in Figure 4a. The data of the winter samples are not discussed due to contamination. In spring, the dominant species were found to be $\mathrm{Na}(18.1 \%), \mathrm{Fe}(17.9 \%)$, and $\mathrm{K}(17.5 \%)$, contributing about $53.5 \%$ of the total metallic elements, while $\mathrm{Na}(25.1 \%), \mathrm{Ca}(20.9 \%)$, and $\mathrm{Al}(13.9 \%)$ accounted for $59.9 \%$ of the total components in summer. In autumn, Fe contributed $22.6 \%$, $\mathrm{Al} 22.2 \%$, and $\mathrm{Mg} 21.0 \%$, which accumulated to $65.79 \%$. Notably, $\mathrm{Na}, \mathrm{Fe}, \mathrm{Ca}$, and $\mathrm{Al}$ were mainly distributed in coarse particles that may have come from the earth crust elements and $\mathrm{road} /$ tires [33]. Figure $4 \mathrm{~b}$ shows the fractions of metals in fine particles during different seasons. In spring, the most abundant elements were $\mathrm{Na}(31.6 \%), \mathrm{Ag}(12.3 \%)$, and $\mathrm{Fe}$ $(11.2 \%)$, while in summer, the proportions of $\mathrm{Na}, \mathrm{Ca}$, and $\mathrm{Al}$ were $29.1,22.5$, and $12.4 \%$, respectively. In autumn, the dominant species were found to be $\mathrm{Al}(28.3 \%), \mathrm{K}(16.7 \%)$, and $\mathrm{Mg}(15.4 \%)$, accounting for $60.4 \%$ of total elements. In addition, $\mathrm{Ag}$ was measured in fine particles that came from anthropogenic sources, such as the iron and steel industries, the cement industry, the combustion of coal and oil, and incineration [34-37]. According to the national emissions inventory of sources and emissions of silver [37], the principal sources (after emission control, if any) are the iron and steel industries (46\%), the cement industry $(25.7 \%)$, the combustion of coal and oil $(13.6 \%)$, and incinerators (5.6\%). Fe was also the most abundant element that was sourced from the Earth's crust [38]. Hence, the major elements in the fine particles were $\mathrm{Na}, \mathrm{Fe}, \mathrm{Ca}$, and $\mathrm{Al}$. In China, the crustal elements $\mathrm{Al}, \mathrm{Ca}$, $\mathrm{K}, \mathrm{Na}, \mathrm{Mg}$, and Fe were most abundant at an industrial site, which may be due to more 
vehicle emissions and dust resuspension [24]. Figure 4c shows the fraction of metals in ultrafine particles in different seasons. In spring, the dominant species were found to be $\mathrm{Na}$ $(23.4 \%), \mathrm{K}(18.8 \%)$, and $\mathrm{Ca}(18.1 \%)$. On the other hand, the fractions of $\mathrm{Na}, \mathrm{Ca}$, and $\mathrm{Al}$ were $30.8 \%, 23.4 \%$, and $11.8 \%$, respectively, in summer. In autumn, the dominant species were $\mathrm{Al}(24.5 \%), \mathrm{Fe}(19.7 \%)$, and $\mathrm{K}(14.9 \%)$, accounting for $59.1 \%$ of the total metallic elements. As a result, the most abundant species in the ultrafine particles were $\mathrm{Na}, \mathrm{K}, \mathrm{Ca}$, and $\mathrm{Al}$.

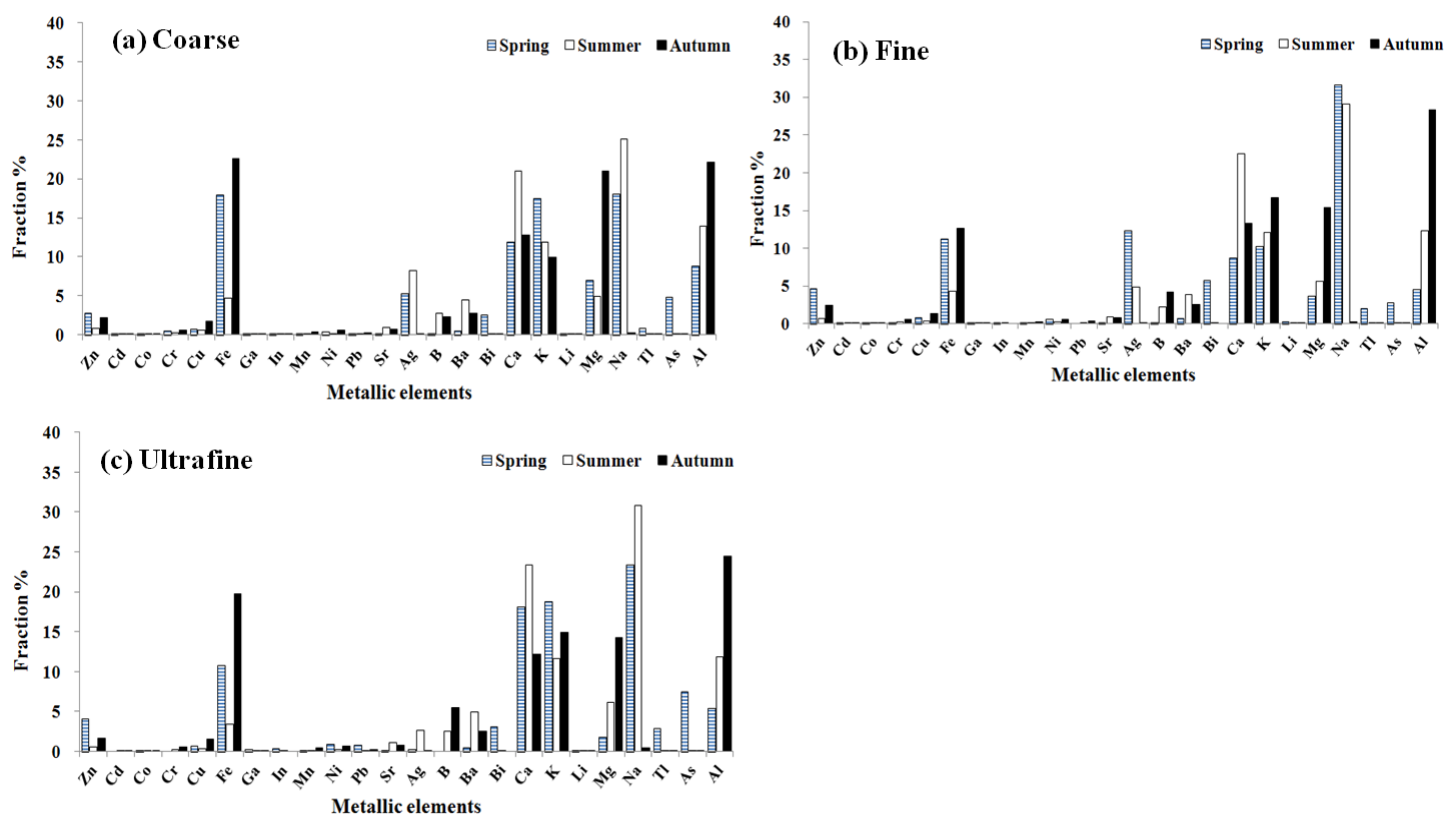

Figure 4. The fraction of metallic elements in different seasons (a): Coarse particles; (b): Fine particles; (c): Ultrafine particles.

Pearson's correlation coefficients of heavy metals in coarse, fine, and ultrafine particles are summarized in Figure 5. By analyzing the value of the correlation coefficient between the metal elements, it is possible to understand the possible sources of air pollution around the sampling point. The significant correlations of Fe-Mn ( $r=0.664-0.965)$, Fe- $\mathrm{Zn}(\mathrm{r}=0.638-0.826)$, and Mn- $\mathrm{Zn}$ $(r=0.127-0.779)$ were observed in coarse, fine, and ultrafine particles, with the exception of Zn-Mn (0.127) in ultrafine particles, suggesting possible iron and steelmaking industry activities near the sampling site. This result agrees with a previous study conducted by Mohiuddin et al. (2014), which analyzed the correlation of Fe-Mn- $\mathrm{Zn}$ from iron and steel industry sites [39]. In Agra, India, Fe shows a good correlation with $\mathrm{Mn}(0.605), \mathrm{Pb}(0.506), \mathrm{Cr}(0.957)$, and $\mathrm{Al}(0.580)$, indicating emissions sources such as the iron or steel industries and crustal materials contribute to ambient air pollution [40]. As shown in Figure 5, $\mathrm{Pb}$ displayed significant correlation $(p<0.05)$ with $\mathrm{Zn}(\mathrm{r}=0.607-0.684), \mathrm{Cr}(\mathrm{r}=0.772-0.914)$, $\mathrm{Fe}(\mathrm{r}=0.555-0.720)$, and $\mathrm{Al}(\mathrm{r}=0.684-0.737)$ in both coarse and fine particles, illustrating the contribution of crustal emissions and coal burning. The results of the statistical analyses by PCA showed that the factors loaded with $\mathrm{Co}, \mathrm{Cd}, \mathrm{Pb}, \mathrm{Ni}, \mathrm{Cu}$, and $\mathrm{Zn}$ are anthropogenic emissions from the combustion of fossil fuels and industry in the ambient air in the central Himalayan region, Nepal [41]. High correlations were observed between Al-Cu $(r=0.718-0.891)$, Al-Sr $(r=0.782-0.864)$, Al-K $(r=0.629-0.856), \mathrm{K}-\mathrm{Sr}(\mathrm{r}=0.380-0.662)$, and $\mathrm{Sr}-\mathrm{Cu}(\mathrm{r}=0.531-0.726)$ in coarse, fine and ultrafine particles (see Figure 5), indicating the contribution from the vehicle exhausts. These results are similar to the findings from the Pittsburgh metropolitan area; that is, $\mathrm{Al}, \mathrm{K}, \mathrm{Mo}, \mathrm{Sb}$, $\mathrm{Sr}$, and $\mathrm{Cu}$ are related to the characteristics of vehicle emissions. Notably, $\mathrm{Mo}, \mathrm{Sb}, \mathrm{Sr}$, and $\mathrm{Cu}$ are related to brake and tire wear [42]. The sampling site (THU) is near the Central Taiwan Science Park (CTSP), which is a high-tech, industry-intensive area. Therefore, positive correlations were observed between $\mathrm{Zn}-\mathrm{Cu}(\mathrm{r}=0.638-0.782), \mathrm{Cd}-\mathrm{Cr}(\mathrm{r}=0.679-0.943), \mathrm{Cd}-\mathrm{Pb}(\mathrm{r}=0.638-0.675)$, $\mathrm{Cu}-\mathrm{Ga} \mathrm{r}=(0.444-0.689), \mathrm{Pb}-\mathrm{K}(\mathrm{r}=0.493-0.652)$, and In-Bi $(\mathrm{r}=0.409-0.600)$. Some correlations between two metals (Cd-V, Cu-Ga, $\mathrm{Zn}-\mathrm{Cu}$, Mo-As, $\mathrm{Pb}-\mathrm{As}, \mathrm{Pb}-\mathrm{Cd}, \mathrm{K}-\mathrm{V}, \mathrm{K}-\mathrm{Pb}$, and $\mathrm{Cr}-\mathrm{Cd}$ ) had a 
greater confidence level and correlation coefficient in the CTSP [43] because the CTSP is a major contributor to $\mathrm{Ga}$ and As in ultrafine particles [44].
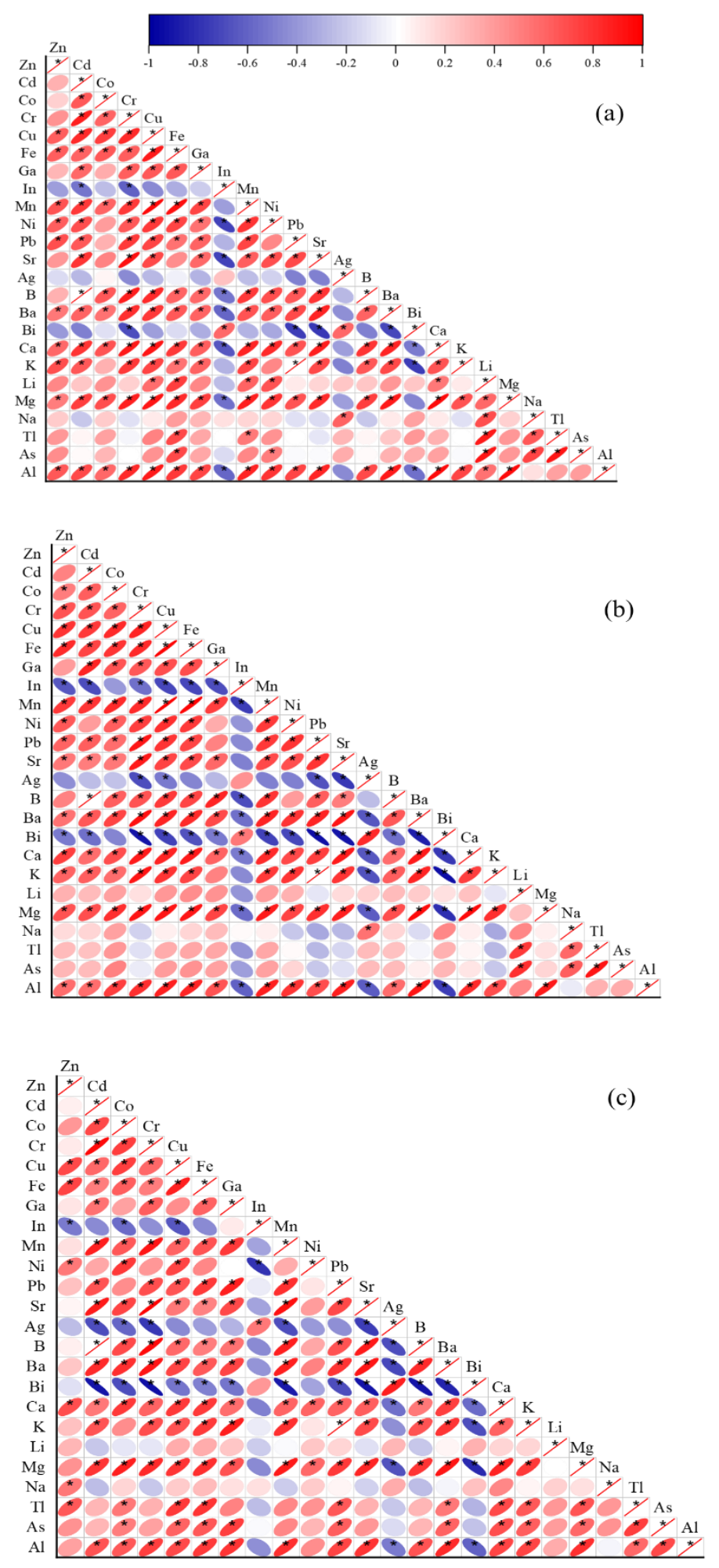

Figure 5. Correlations among metal elements for (a) coarse, (b) fine, and (c) ultrafine particles in sampling periods. *: $p \leq 0.05$. 


\subsection{PCDD/F Concentration in Ambient Air}

The measured species and concentrations of $\mathrm{PCDD} / \mathrm{F}$ are listed in Table 3. In 2017, the total concentrations of PCDD/F were 0.2541 and $0.1387 \mathrm{pg} / \mathrm{Nm}^{3}$ in the spring and summer, respectively. The corresponding I-TEQ concentrations were $0.0017 \mathrm{pg}$ I-TEQ $/ \mathrm{Nm}^{3}$ in spring and $0.0006 \mathrm{pg}$ I-TEQ/ $\mathrm{Nm}^{3}$ in summer 2017. This result is consistent with the findings of atmospheric PCDD/Fs ranging from 0.97 to $255 \mathrm{fg} \mathrm{I}-\mathrm{TEQ} / \mathrm{m}^{3}$ in 11-year observations in Taiwan [45]. Those values were slightly lower than those in the previous study in southern Taiwan (0.0319-0.0847 pg I-TEQ/ $\mathrm{Nm}^{3}$ ) [46,47]. A study in Southeast Asia showed that the ambient levels were 15 times greater in urban areas than in rural areas, varying from 23 to $565 \mathrm{fg}^{\mathrm{T}} \mathrm{TEQ} \mathrm{m} \mathrm{m}^{-3}$ [48]. In addition, the present results were much lower than the regulation values of ambient air PCDD/F concentrations in Japan $\left(0.6 \mathrm{pg} \mathrm{I-TEQ/} \mathrm{Nm}^{3}\right)$. As shown in Table 3, the main species of measured PCDD/F were 1,2,3,7,8,9-Hexachlorodibenzo- $p$ dioxin (1,2,3,7,8,9-HxCDD), 1,2,3,4,6,7,8-Heptachlorodibenzo- $p$-dioxin (1,2,3,4,6,7,8-HpCDD), 1,2,3,7,8,9-Hexachlorodibenzofuran (1,2,3,7,8,9-HxCDF), 2,3,4,6,7,8-Hexachlorodibenzofuran (2,3,4,6,7,8-HxCDF), 1,2,3,4,6,7,8- Heptachlorodibenzofuran (1,2,3,4,6,7,8-HpCDF), and Octachlorodibenzofuran (OCDF), which were similar to the dominant congeners of OCDD, OCDF, 1,2,3,4,6,7,8-HpCDF, and 1,2,3,4,6,7,8-HpCDD in Taiwan's atmosphere [49].

Table 3. PCDD/F concentration $\left(\mathrm{pg} / \mathrm{m}^{3}\right)$ in ambient air.

\begin{tabular}{|c|c|c|}
\hline $\mathrm{PCDD} / \mathrm{F}$ & Spring, 2017 & Summer, 2017 \\
\hline 2,3,7,8-TeCDD & ND & ND \\
\hline 1,2,3,7,8-PeCDD & ND & ND \\
\hline $1,2,3,4,7,8-\mathrm{HxCDD}$ & ND & ND \\
\hline $1,2,3,6,7,8-\mathrm{HxCDD}$ & ND & ND \\
\hline 1,2,3,7,8,9-HxCDD & ND & ND \\
\hline $1,2,3,4,6,7,8-H p C D D$ & 0.0377 & 0.0177 \\
\hline OCDD & 0.1042 & 0.0488 \\
\hline 2,3,7,8-TeCDF & ND & ND \\
\hline 1,2,3,7,8-PeCDF & ND & ND \\
\hline $2,3,4,7,8-\mathrm{PeCDF}$ & ND & ND \\
\hline $1,2,3,4,7,8-\mathrm{HxCDF}$ & ND & ND \\
\hline $1,2,3,6,7,8-\mathrm{HxCDF}$ & ND & ND \\
\hline $1,2,3,7,8,9-\mathrm{HxCDF}$ & 0.0068 & ND \\
\hline $2,3,4,6,7,8-\mathrm{HxCDF}$ & 0.0013 & ND \\
\hline 1,2,3,4,6,7,8-HpCDF & 0.0341 & 0.0288 \\
\hline $1,2,3,4,7,8,9-\mathrm{HpCDF}$ & ND & ND \\
\hline OCDF & 0.0699 & 0.0434 \\
\hline PCDDs & 0.1122 & 0.0722 \\
\hline PCDFs & 0.1418 & 0.0665 \\
\hline PCDDs/PCDFs ratio & 1.26 & 0.92 \\
\hline Total PCDD/DFs & 0.2541 & 0.1387 \\
\hline PCDDs I-TEQ ${ }^{a}$ & 0.0005 & 0.0002 \\
\hline PCDFs I-TEQ ${ }^{\mathrm{a}}$ & 0.0012 & 0.0003 \\
\hline PCDDs/PCDFs(TEQ) ratio & 0.39 & 0.68 \\
\hline $\mathrm{I}-\mathrm{TEQ}^{\mathrm{a}}$ & 0.0017 & 0.0006 \\
\hline
\end{tabular}

a The unit is pg I-TEQ/ $\mathrm{Nm}^{3}$.

\subsection{Source Identification by Principal Component Analysis}

In order to estimate the possible emission sources for PMs, the PCA model was used in this study. The PCA for water-soluble ions is listed in Table 4 . The total value was over $79.8 \%$ of the explained variance. The $\mathrm{PC} 1$ had high loadings of $\mathrm{Cl}^{-}, \mathrm{Na}^{+}, \mathrm{F}^{-}$, and $\mathrm{Mg}^{2+}$ with a maximum percentage of variance of $46.94 \%$. The $\mathrm{Na}^{+}, \mathrm{Mg}^{2+}$, and $\mathrm{Cl}^{-}$may come from sea salt, while $\mathrm{F}^{-}$may come from industrial processes [50]. The PC2 consisted of $\mathrm{NO}_{3}{ }^{-}$and $\mathrm{SO}_{4}{ }^{2-}$, with $32.92 \%$ of the total variance comprised of secondary pollutants formed by photochemical reactions [51-53]. 
Table 4. Principal component analysis (PCA) for water-soluble ions. The bold means it emphasize the strong related ions to each Factors.

\begin{tabular}{ccc}
\hline Water-Soluble Ions & Factor $\mathbf{1}$ & Factors 2 \\
\hline $\mathrm{Na}^{+}$ & $\mathbf{0 . 8 3 1}$ & 0.324 \\
$\mathrm{NH}_{4}^{+}$ & -0.711 & 0.657 \\
$\mathrm{~K}^{+}$ & -0.449 & 0.138 \\
$\mathrm{Ca}^{2+}$ & 0.184 & -0.365 \\
$\mathrm{Mg}^{2+}$ & $\mathbf{0 . 7 8 1}$ & 0.064 \\
$\mathrm{~F}^{-}$ & $\mathbf{0 . 8 2 1}$ & -0.110 \\
$\mathrm{Cl}^{-}$ & $\mathbf{0 . 8 7 0}$ & 0.109 \\
$\mathrm{NO}_{3}{ }^{-}$ & 0.163 & $\mathbf{0 . 9 5 0}$ \\
$\mathrm{SO}_{4}^{2-}$ & 0.487 & $\mathbf{0 . 7 1 9}$ \\
$\%$ of Variance & 46.942 & 32.921 \\
Cumulative \% & 46.942 & 79.864 \\
Possible sources & Sea salt & Secondary pollutants \\
\hline
\end{tabular}

\section{Conclusions}

In this study, we successfully characterized the PMs with size distributions, ion and cation compositions, metals, and PCDD/F concentrations in an industry-intensive area in central Taiwan. Coarse particles were dominant in spring and summer, with an average mass concentration of 16.96 and $12.67 \mu \mathrm{g} / \mathrm{m}^{3}$, accounting for 47.5 and $45.6 \%$, respectively. Fine particle concentrations were 15.39 and $18.17 \mu \mathrm{g} / \mathrm{m}^{3}$ in autumn and winter, accounting for 46.7 and $62.2 \%$, respectively. The sequence of the major ionic species in the coarse particles were $\mathrm{Cl}^{-}\left(1.63 \mu \mathrm{g} / \mathrm{m}^{3}\right)>\mathrm{NO}_{3}{ }^{-}\left(1.62 \mu \mathrm{g} / \mathrm{m}^{3}\right)>\mathrm{SO}_{4}{ }^{2-}\left(1.18 \mu \mathrm{g} / \mathrm{m}^{3}\right)$, whereas the sequence was $\mathrm{SO}_{4}{ }^{2-}\left(2.32 \mu \mathrm{g} / \mathrm{m}^{3}\right)>\mathrm{Cl}^{-}\left(1.37 \mu \mathrm{g} / \mathrm{m}^{3}\right)>\mathrm{NO}_{3}{ }^{-}\left(1.30 \mu \mathrm{g} / \mathrm{m}^{3}\right)$ in the fine particles. In addition, the largest metal components were $\mathrm{Na}, \mathrm{Fe}, \mathrm{Ca}, \mathrm{Al}$, and $\mathrm{Mg}$ in different particle sizes. The measured PCDD/F concentrations ranged from 0.0006 to $0.0017 \mathrm{pg}$ I-TEQ/ $/ \mathrm{Nm}^{3}$. According to the results of PCA, the contribution to PMs were associated with sea salt, secondary pollutants, and industrial process.

Author Contributions: Conceptualization, Y.-P.P. and M.-H.L.; methodology, H.-W.L.; investigation, T.-Y.C., Y.-C.L. (Yi-Ching Lin) and C.-H.C.; resources, Y.-C.L. (Yung-Chang Lin); data curation, C.-H.L.; writing-original draft preparation, H.-W.L. and Y.-P.P.; writing—review and editing, H.-W.L., Y.-P.P. and M.-H.L.; supervision, K.-S.C. All authors have read and agreed to the published version of the manuscript.

Funding: This study is funded by Tunghai University, Taiwan.

Institutional Review Board Statement: This study did not involve humans or animals.

Informed Consent Statement: This study did not involve humans.

Data Availability Statement: Data is contained within the article.

Acknowledgments: The authors acknowledge Chia-Hung Chen and Chinh-Chen Liu for their help in sampling and analysis work.

Conflicts of Interest: The authors declare no conflict of interest.

\section{References}

1. WHO. Health Risk of Particulate Matter from Long-Rang Transboundary Air Pollution, Joint WHO/Convention Task Force on the Health Aspects of Air Pollution; World Health Organization Regional Office for Europe: Copenhagen, Denmark, 2006.

2. Hinds, W.C. Aerosol Technology, Introduction, 2nd ed.; John Wiley and Sons: New York, NY, USA, 1999.

3. Tecer, L.H.; Alagha, O.; Karaca, F.; Tuncel, G.; Eldes, N. Particulate matter (PM2.5, PM10-2.5, and PM10) and children's hospital admissions for asthma and respiratory diseases: A bidirectional case-crossover study. J. Toxicol. Environ. Health Part A 2008, 71, 512-520. [CrossRef]

4. Hughes, L.S.; Cass, G.R.; Gone, J.; Ames, M.; Olmez, I. Physical and chemical characterization of atmospheric ultrafine particles in the Los Angeles area. Environ. Sci. Technol. 1998, 32, 1153-1161. [CrossRef] 
5. Harrison, R.M.; Shi, J.P.; Xi, S.; Khan, A.; Mark, D.; Kinnersley, R.; Yin, J. Measurement of number, mass and size distribution of particles in the atmosphere. Philosophical Transactions of the Royal Society of London. Ser. A Math. Phys. Eng. Sci. 2000, 358, 2567-2580. [CrossRef]

6. United States Environmental Protection Agency. Exposure and Human Health Reassessment of 2,3,7,8-Tetrachlorodibenzo-p-Dioxin (TCDD) and Related Compounds National Academy Sciences Review Draft; United States Environmental Protection Agency: Washington, DC, USA, 2000.

7. Lai, C.-H.; Lin, C.-H.; Liao, C.-C. Respiratory deposition and health risk of inhalation of particle-bound heavy metals in the carbon black feeding area of a tire manufacturer. Air Qual. Atmos. Health 2017, 10, 1281-1289. [CrossRef]

8. Han, Y.-J.; Kim, T.-S.; Kim, H. Ionic constituents and source analysis of PM2. 5 in three Korean cities. Atmos. Environ. 2008, 42, 4735-4746. [CrossRef]

9. Tsai, J.-H.; Lin, J.-H.; Yao, Y.-C.; Chiang, H.-L. Size distribution and water soluble ions of ambient particulate matter on episode and non-episode days in Southern Taiwan. Aerosol Air Qual. Res. 2011, 12, 263-274. [CrossRef]

10. Masri, S.; Kang, C.-M.; Koutrakis, P. Composition and sources of fine and coarse particles collected during 2002-2010 in Boston, MA. J. Air Waste Manag. Assoc. 2015, 65, 287-297. [CrossRef]

11. Vega, E.; Ruiz, H.; Escalona, S.; Cervantes, A.; Lopez-Veneroni, D.; Gonzalez-Avalos, E.; Sanchez-Reyna, G. Chemical composition of fine particles in Mexico City during 2003-2004. Atmos. Pollut. Res. 2011, 2, 477-483. [CrossRef]

12. Lohmann, R.; Jones, K.C. Dioxins and furans in air and deposition: A review of levels, behaviour and processes. Sci. Total Environ. 1998, 219, 53-81. [CrossRef]

13. Hippelein, M.; Kaupp, H.; Dörr, G.; McLachlan, M. Testing of a sampling system and analytical method for determination of semivolatile organic compounds in ambient air. Chemosphere 1993, 26, 2255-2263. [CrossRef]

14. United States Environmental Protection Agency. Determination of Polychlorinated, Polybrominated and Brominated/Chlorinated Dibenzo-p-Dioxins and Dibenzofurans in Ambient Air, Compendium Method TO-9A; United States Environmental Protection Agency: Washington, DC, USA, 1999.

15. Hopke, P.K. Review of receptor modeling methods for source apportionment. J. Air Waste Manag. Assoc. 2016, 66, 237-259. [CrossRef]

16. Hopke, P.K. Receptor Modeling in Environmental Chemistry; John Wiley \& Sons: Hoboken, NJ, USA, 1985.

17. Marcazzan, G.; Ceriani, M.; Valli, G.; Vecchi, R. Source apportionment of PM10 and PM2. 5 in Milan (Italy) using receptor modelling. Sci. Total Environ. 2003, 317, 137-147. [CrossRef]

18. Saradhi, I.; Prathibha, P.; Hopke, P.K.; Pandit, G.; Puranik, V.J.A.; Research, A.Q. Source apportionment of coarse and fine particulate matter at Navi Mumbai, India. Aerosol Air Qual. Res. 2008, 8, 423-436.

19. Lü, S.; Zhang, R.; Yao, Z.; Yi, F.; Ren, J.; Wu, M.; Feng, M.; Wang, Q. Size distribution of chemical elements and their source apportionment in ambient coarse, fine, and ultrafine particles in Shanghai urban summer atmosphere. J. Environ. Sci. 2012, 24, 882-890. [CrossRef]

20. Ntziachristos, L.; Ning, Z.; Geller, M.D.; Sheesley, R.J.; Schauer, J.J.; Sioutas, C. Fine, ultrafine and nanoparticle trace element compositions near a major freeway with a high heavy-duty diesel fraction. Atmos. Environ. 2007, 41, 5684-5696. [CrossRef]

21. Fang, G.-C.; Chang, C.-N.; Wu, Y.-S.; Fu, P.P.-C.; Yang, C.-J.; Chen, C.-D.; Chang, S.-C. Ambient suspended particulate matters and related chemical species study in central Taiwan, Taichung during 1998-2001. Atmos. Environ. 2002, 36, 1921-1928. [CrossRef]

22. Tsai, H.-H.; Yuan, C.-S.; Hung, C.-H.; Lin, Y.-C. Comparing physicochemical properties of ambient particulate matter of hot spots in a highly polluted air quality zone. Aerosol Air Qual. Res. 2010, 10, 331-344. [CrossRef]

23. Gupta, A.; Nag, S.; Mukhopadhyay, U. Characterisation of PM 10, PM 2.5 and benzene soluble organic fraction of particulate matter in an urban area of Kolkata, India. Environ. Monit. Assess. 2006, 115, 205-222. [CrossRef]

24. Huang, B.; Liu, M.; Ren, Z.; Bi, X.; Zhang, G.; Sheng, G.; Fu, J. Chemical composition, diurnal variation and sources of PM2. 5 at two industrial sites of South China. Atmos. Pollut. Res. 2013, 4, 298-305. [CrossRef]

25. Turnbull, A.B.; Harrison, R.M. Major component contributions to PM10 composition in the UK atmosphere. Atmos. Environ. 2000, 34, 3129-3137. [CrossRef]

26. Huang, R.-J.; Zhang, Y.; Bozzetti, C.; Ho, K.-F.; Cao, J.-J.; Han, Y.; Daellenbach, K.R.; Slowik, J.G.; Platt, S.M.; Canonaco, F. High secondary aerosol contribution to particulate pollution during haze events in China. Nature 2014, 514, 218-222. [CrossRef]

27. Bourotte, C.; Curi-Amarante, A.-P.; Forti, M.-C.; Pereira, L.A.; Braga, A.L.; Lotufo, P.A. Association between ionic composition of fine and coarse aerosol soluble fraction and peak expiratory flow of asthmatic patients in São Paulo city (Brazil). Atmos. Environ. 2007, 41, 2036-2048. [CrossRef]

28. Cheng, H.; Gong, W.; Wang, Z.; Zhang, F.; Wang, X.; Lv, X.; Liu, J.; Fu, X.; Zhang, G. Ionic composition of submicron particles (PM1.0) during the long-lasting haze period in January 2013 in Wuhan, central China. J. Environ. Sci. 2014, 26, 810-817. [CrossRef]

29. Shen, Z.; Cao, J.; Arimoto, R.; Han, Z.; Zhang, R.; Han, Y.; Liu, S.; Okuda, T.; Nakao, S.; Tanaka, S. Ionic composition of TSP and PM2.5 during dust storms and air pollution episodes at Xi'an, China. Atmos. Environ. 2009, 43, 2911-2918. [CrossRef]

30. Deshmukh, D.K.; Deb, M.K.; Tsai, Y.I.; Mkoma, S.L.; Research, A.Q. Water soluble ions in PM2. 5 and PM1 aerosols in Durg city, Chhattisgarh, India. Aerosol Air Qual. Res. 2011, 11, 696-708. [CrossRef]

31. Dongarrà, G.; Manno, E.; Varrica, D.; Lombardo, M.; Vultaggio, M. Study on ambient concentrations of PM10, PM10-2.5, PM2. 5 and gaseous pollutants. Trace elements and chemical speciation of atmospheric particulates. Atmos. Environ. 2010, 44, 5244-5257. [CrossRef] 
32. Yan, J.; Lai, C.-H.; Lung, S.-C.C.; Chen, C.; Wang, W.-C.; Huang, P.-I.; Lin, C.-H. Industrial PM2. 5 cause pulmonary adverse effect through RhoA/ROCK pathway. Sci. Total Environ. 2017, 599, 1658-1666. [CrossRef]

33. Wåhlin, P.; Berkowicz, R.; Palmgren, F. Characterisation of traffic-generated particulate matter in Copenhagen. Atmos. Environ. 2006, 40, 2151-2159. [CrossRef]

34. López, J.; Callén, M.; Murillo, R.; Garcia, T.; Navarro, M.; De la Cruz, M.; Mastral, A. Levels of selected metals in ambient air PM10 in an urban site of Zaragoza (Spain). Environ. Res. 2005, 99, 58-67. [CrossRef]

35. Rahn, K.A. A graphical technique for determining major components in a mixed aerosol. I. Descriptive aspects. Atmos. Environ. 1999, 33, 1441-1455. [CrossRef]

36. Zhi, M.; Zhang, X.; Zhang, K.; Ussher, S.J.; Lv, W.; Li, J.; Gao, J.; Luo, Y.; Meng, F. The characteristics of atmospheric particles and metal elements during winter in Beijing: Size distribution, source analysis, and environmental risk assessment. Ecotoxicol. Environ. Saf. 2021, 211, 111937. [CrossRef]

37. United States Environmental Protection Agency. National Emissions Inventory of Sources and Emissions of Silver; Office of Air and Water Programs; United States Environmental Protection Agency: Washington, DC, USA, 1973.

38. Taner, S.; Pekey, B.; Pekey, H. Fine particulate matter in the indoor air of barbeque restaurants: Elemental compositions, sources and health risks. Sci. Total Environ. 2013, 454, 79-87. [CrossRef] [PubMed]

39. Mohiuddin, K.; Strezov, V.; Nelson, P.; Stelcer, E. Characterisation of trace metals in atmospheric particles in the vicinity of iron and steelmaking industries in Australia. Atmos. Environ. 2014, 83, 72-79. [CrossRef]

40. Agarwal, A.; Mangal, A.; Satsangi, A.; Lakhani, A.; Kumari, K.M. Characterization, sources and health risk analysis of PM2.5 bound metals during foggy and non-foggy days in sub-urban atmosphere of Agra. Atmos. Res. 2017, 197, 121-131. [CrossRef]

41. Tripathee, L.; Kang, S.; Huang, J.; Sharma, C.M.; Sillanpää, M.; Guo, J.; Paudyal, R. Concentrations of trace elements in wet deposition over the central Himalayas, Nepal. Atmos. Environ. 2014, 95, 231-238. [CrossRef]

42. Tunno, B.J.; Dalton, R.; Michanowicz, D.R.; Shmool, J.L.; Kinnee, E.; Tripathy, S.; Cambal, L.; Clougherty, J.E. Spatial patterning in PM 2.5 constituents under an inversion-focused sampling design across an urban area of complex terrain. J. Expo. Sci. Environ. Epidemiol. 2016, 26, 385-396. [CrossRef]

43. Chen, H.-W.; Chen, W.-Y.; Chang, C.-N.; Chuang, Y.-H.; Lin, Y.-H. Identifying airborne metal particles sources near an optoelectronic and semiconductor industrial park. Atmos. Res. 2016, 174, 97-105. [CrossRef]

44. Chen, W.-Y.; Chen, H.-W.; Chang, C.-N.; Lin, Y.-H.; Chuang, Y.-H.; Lin, Y.-C.; Research, A.Q. Particles and metallic elements near a high-tech industrial park: Analysis of size distributions. Aerosol Air Qual. Res. 2015, 15, 1787-1798. [CrossRef]

45. Ngo, T.H.; Yang, Y.-H.; Chen, Y.-C.; Pan, W.C.; Chi, K.H. Continuous nationwide atmospheric PCDD/F monitoring network in Taiwan (2006-2016): Variation in concentrations and apportionment of emission sources. Chemosphere 2020, 255, 126979. [CrossRef] [PubMed]

46. Hsieh, L.-T.; Wang, Y.-F.; Kuo, G.-H.; Wang, L.-C.; Chang-Chien, G.-P. Cluster analysis for polychlorinated dibenzo-p-dioxins and dibenzofurans concentrations in southern Taiwan. J. Air Waste Manag. Assoc. 2009, 59, 1474-1480. [CrossRef]

47. Wang, J.B.; Chang-Chien, G.-P.; Lin, W.-Y.; Yeh, J.-H.; Hung, C.-H. A seasonality study of polychlorinated dibenzo-p-dioxins and dibenzofurans in ambient air in Kaohsiung (Taiwan) clustered with metallurgical industries. J. Hazard. Mater. 2009, 162, 103-110. [CrossRef]

48. Zain, S.M.S.M.; Latif, M.T.; Baharudin, N.H.; Anual, Z.F.; Hanif, N.M.; Khan, M.F. Atmospheric PCDDs/PCDFs levels and occurrences in Southeast Asia: A review. Sci. Total Environ. 2021, 783, 146929. [CrossRef] [PubMed]

49. Li, H.-W.; Wu, Y.-L.; Lee, W.-J.; Chang-Chien, G.-P. Fate of polychlorinated dibenzo-p-dioxins and dibenzofurans in a fly ash treatment plant. J. Air Waste Manag. Assoc. 2007, 57, 1024-1031. [CrossRef]

50. Quinn, P.; Miller, T.; Bates, T.; Ogren, J.; Andrews, E.; Shaw, G. A 3-year record of simultaneously measured aerosol chemical and optical properties at Barrow, Alaska. J. Geophys. Res. Atmos. 2002, 107, AAC 8-1-AAC 8-15. [CrossRef]

51. Kleeman, M.J.; Schauer, J.J.; Cass, G.R. Size and composition distribution of fine particulate matter emitted from motor vehicles. Environ. Sci. Technol. 2000, 34, 1132-1142. [CrossRef]

52. Watson, J.G.; Chow, J.C.; Lurmann, F.W.; Musarra, S.P. Ammonium nitrate, nitric acid, and ammonia equilibrium in wintertime Phoenix, Arizona. Air Waste 1994, 44, 405-412. [CrossRef]

53. Seinfeld, J.H.; Pandis, S.N. Atmospheric Chemistry and Physics: From Air Pollution to Climate Change; John Wiley \& Sons: Hoboken, NJ, USA, 2016. 